\title{
SURVIVAL OF PORCINE REPRODUCTIVE AND RESPIRATORY SYNDROME VIRUS IN FRESH PORK
}

\author{
Helena GUARINO ${ }^{1}$, Junior MOURA ${ }^{2}$, Ryan B. COX ${ }^{2}$, Sagar M. GOYAL ${ }^{1}$ \\ and Devi P. PATNAYAK ${ }^{1 *}$ \\ ${ }^{1}$ Departments of Veterinary Population Medicine and ${ }^{2}$ Animal Science, \\ University of Minnesota, 1333 Gortner Avenue, St. Paul, MN 55108, USA
}

(Received 9 February 2013; accepted 2 April 2013)

Porcine reproductive and respiratory syndrome virus (PRRSV) remains one of the most economically important diseases of pigs. Transmission of PRRS virus has been reported through many routes, with aerosol route being the most predominant. There may also be a potential risk of transmission through contaminated pork, but this has never been investigated. The purpose of this study was to experimentally contaminate fresh pork with three different concentrations of PRRSV and to study virus survival at ambient $\left(25^{\circ} \mathrm{C}\right)$, refrigerated $\left(4^{\circ} \mathrm{C}\right)$, and frozen $\left(-20^{\circ} \mathrm{C}\right)$ temperatures. Concentrations of virus representing natural infectivity level and 'worst case scenario' were studied. The virus was detected in fresh pork at all three virus concentrations for up to $48 \mathrm{~h}$ at ambient temperature. At $4{ }^{\circ} \mathrm{C}$, the virus survived for 6 days in pork inoculated with the higher virus concentration and for 3 days in pork inoculated at the lower concentration. At frozen temperature, PRRSV was detected for up to 60 days in pork inoculated at the higher concentration and for 7 days in pork inoculated at the lower concentration. These results suggest that fresh pork has the potential to be a vehicle for virus dissemination depending upon temperature and time of storage.

Key words: Porcine reproductive and respiratory syndrome virus, pork contamination, swine, virus transmission, virus survival

Porcine reproductive and respiratory syndrome (PRRS) is an economically important disease of swine and is widely recognised in the major swineproducing countries of the world. The disease affects pigs of all ages and manifests itself as reproductive failure in sows and gilts and pneumonia in piglets. It has been estimated that PRRS costs the US swine industry approximately $\$ 560$ million annually (Neumann et al., 2005). The disease is caused by an enveloped RNA virus, namely the porcine reproductive and respiratory syndrome virus (PRRSV) belonging to the family Arteriviridae. Like many enveloped viruses, PRRSV is sensitive to lipid solvents and to environmental insult (Benfield et al.,

"Corresponding author; E-mail: patn0016@umn.edu; Phone: 001 (612) 626-2712; Fax: 001 (612) 624-8707 
1992). The possibility of virus introduction into PRRSV-free countries via the importation of pork has become a recent trade concern (Farez and Morley, 1997).

Studies on virus transmission indicate that, on a herd level, PRRSV may be introduced by the purchase and introduction of PRRSV-infected pigs, the use of contaminated semen, equipment (Otake et al., 2002a) or transportation vehicles (Dee et al., 2004), insect vectors (Otake et al., 2002b, 2003, 2004) and via air (Mortensen et al., 2002). Low concentrations of PRRSV have been detected in muscle samples of experimentally infected pigs (Bloemraad et al., 1994; Magar et al., 1995; Mengeling et al., 1995), indicating the possibility of oral transmission through infected pork. In fact, oral transmission in pigs was demonstrated by using a PRRSV suspension (Magar and Larochelle, 2004) and via the feeding of pork obtained from recently infected pigs (van der Linden et al., 2003). The virus has also been detected occasionally in abattoir meat samples (Frey et al., 1995). Several risk analysis studies have been performed to evaluate the probability of introduction of PRRSV through pork products to PRRS-free countries or farms (Mortensen et al., 2002). However, relatively few studies are available on the stability of PRRSV in pork. The objective of the present study was to determine the viability of PRRSV in experimentally inoculated fresh pork at three different temperatures.

\section{Materials and methods}

Virus

The North American prototype strain of PRRSV (VR2332) was used in this study. The initial titre of the virus was $10^{6} \mathrm{TCID}_{50} / \mathrm{ml}$. Virus doses of $10^{5}$, $10^{4}$ and $10^{3} \mathrm{TCID}_{50} / \mathrm{ml}$ were used to spike pork samples in various experiments.

\section{Virus propagation}

The virus was propagated in 5-day-old MARC-145 cells. The cells were grown in Eagle's MEM supplemented with fetal bovine serum (8\%), $500 \mathrm{IU} / \mathrm{ml}$ of penicillin, $500 \mu \mathrm{g} / \mathrm{ml}$ of streptomycin, $0.15 \mathrm{mg} / \mathrm{ml}$ of neomycin, and $1.5 \mu \mathrm{g} / \mathrm{ml}$ of fungizone. Following observation of cytopathic effect (CPE), the virus was frozen and thawed twice and centrifuged at $2000 \mathrm{rpm}$ for $15 \mathrm{~min}$. The supernatant was titrated, poured in $1-\mathrm{ml}$ aliquots and frozen at $-80^{\circ} \mathrm{C}$ until used.

\section{Virus titration}

Serial 10-fold dilutions of the virus and samples were prepared in maintenance medium (MEM with 2\% FBS and antibiotics) using sterile 96-well plates and $100 \mu \mathrm{l}$ of each dilution was inoculated in 96-well microtitre plates containing confluent monolayers of MARC-145 cells (using 4 wells per dilution). Plates 
were incubated at $37{ }^{\circ} \mathrm{C}$ and $5 \% \mathrm{CO}_{2}$, and read microscopically daily for the appearance of CPE. After 6 days, the medium was discarded and cells were fixed with chilled ethanol for $1 \mathrm{~h}$ at $-20^{\circ} \mathrm{C}$. After ethanol was discarded, the plates were washed twice with phosphate-buffered saline (PBS) and stained with $50 \mu 1$ of fluorescein-conjugated monoclonal antibody SDOW 17 for $2 \mathrm{~h}$ at $37^{\circ} \mathrm{C}$. Plates were read under a fluorescent microscope. The titres were calculated by a standard method (Karber, 1931) and were expressed as $\mathrm{TCID}_{50} / \mathrm{ml}$. The experiment was terminated when at two consecutive time intervals no CPE was present and the IFA test was negative. Titres were calculated in proportion to initial virus concentration, adjusted by the total volume recovered and expressed as the total amount of virus recovery.

\section{Pork samples}

Fresh lean samples of pork were obtained from the longissimus lumborum muscle adjacent to the 10th rib of the carcass. The firm and uniform lean samples were cut, using a standardised grid, in cubes of $1 \mathrm{~cm}^{3}$. A total of 48 cubes of pork were used for each virus.

\section{Sample processing}

Forty-five pork cubes were injected with $100 \mu$ of virus suspension containing $10^{3}, 10^{4}$ or $10^{5} \mathrm{TCID}_{50}$ of the virus and three pork cubes without virus inoculation were used as a negative control. Inoculated cubes were individually placed in 45 plastic bags and kept at three different temperatures: ambient $\left(25^{\circ} \mathrm{C}\right)$, refrigerated $\left(4^{\circ} \mathrm{C}\right)$ and frozen $\left(-20^{\circ} \mathrm{C}\right)$. Pork cubes at room temperature were tested for surviving virus at $0,4,12,24,48$ and $72 \mathrm{~h}$. The aliquots stored at $4{ }^{\circ} \mathrm{C}$ were tested at $3,6,9,12$ and 15 days, while those at $-20{ }^{\circ} \mathrm{C}$ were tested at 7, 15, 30 and 60 days post-inoculation. At each sampling time, suspensions of pork were prepared by adding $5 \mathrm{ml}$ of Hanks' balanced salt solution (HBSS) with $2 \%$ horse serum, $500 \mathrm{IU} / \mathrm{ml}$ of penicillin, $500 \mu \mathrm{g} / \mathrm{ml}$ of streptomycin, $0.15 \mathrm{mg} / \mathrm{ml}$ of neomycin, $1.5 \mu \mathrm{g} / \mathrm{ml}$ of fungizone and $50 \mu \mathrm{g} / \mathrm{ml}$ of gentamicin followed by homogenisation in a Stomacher ${ }^{\circledR}$. Suspensions were decanted into centrifuge tubes and centrifuged at $4,000 \times \mathrm{g}$ for $30 \mathrm{~min}$ at $4{ }^{\circ} \mathrm{C}$. The supernatant was immediately used for virus assay, aliquoted in 1-ml amounts and stored at $-80{ }^{\circ} \mathrm{C}$. The experiment was terminated when no virus was detected at two consecutive time intervals.

\section{Results}

The virus was detected in pork samples for up to $48 \mathrm{~h}$ at all three virus concentrations when stored at ambient room temperature with a sharp decline after the first $24 \mathrm{~h}$ (Fig. 1). No virus was detectable at $72 \mathrm{~h}$ at any of the three con- 
centrations used. At $4{ }^{\circ} \mathrm{C}$, the virus was isolated for up to 6 days at inoculum levels of $10^{5}$ and $10^{4} \mathrm{TCID}_{50}$ but not when $10^{3} \mathrm{TCID}_{50}$ was used (Fig. 3). At $-20^{\circ} \mathrm{C}$, the virus was detected for up to 60 days with the higher concentration and only for 7 days with the lower-titre inoculum (Fig. 2). No virus was isolated from any of the meat samples that were not inoculated with the virus (negative control).

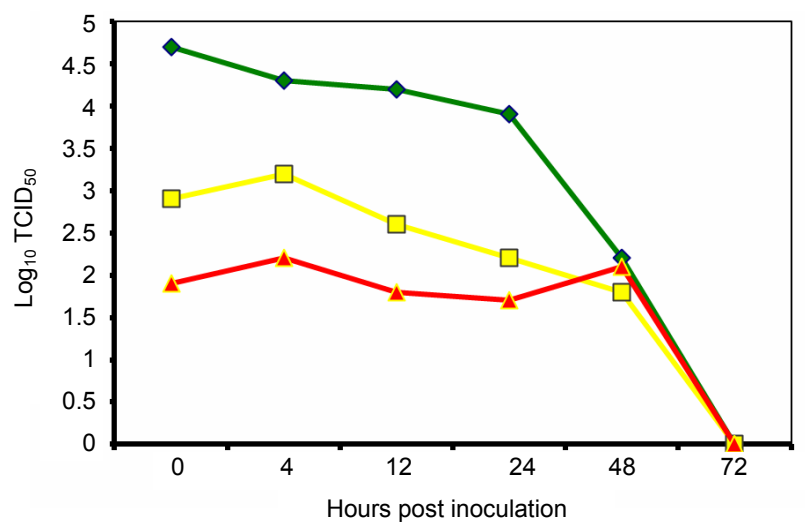

Fig. 1. Survival of PRRS virus in fresh pork at room temperature $\left(25^{\circ} \mathrm{C}\right)$. Lines with $\diamond, \square, \Delta$ represent virus dilution of $10^{5}, 10^{4}$ and $10^{3} \mathrm{TCID}_{50} / \mathrm{ml}$, respectively

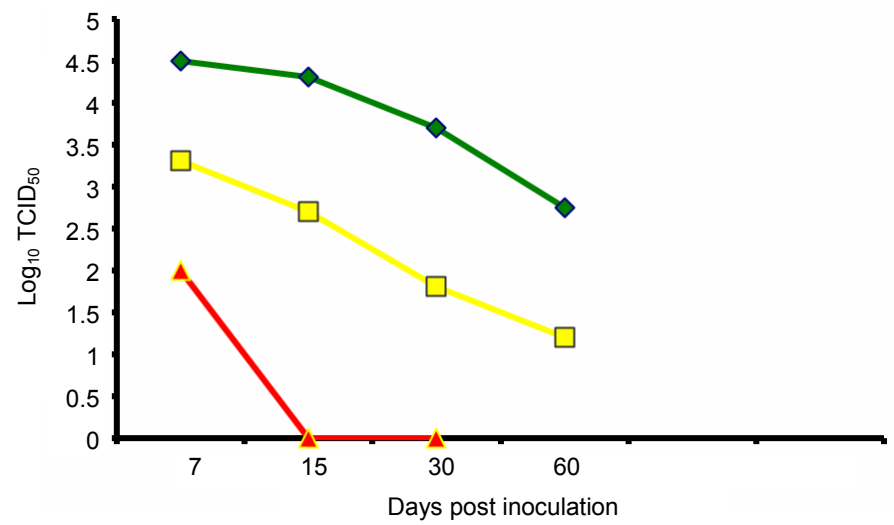

Fig. 2. Survival of PRRS virus in fresh pork at $-20^{\circ} \mathrm{C}$. Lines with $\diamond, \square, \Delta$ represent virus dilution of $10^{5}, 10^{4}$ and $10^{3} \mathrm{TCID}_{50} / \mathrm{ml}$, respectively

\section{Discussion}

Transmission of PRRSV to PRRS-free countries has always been a concern, particularly through import of PRRS-infected animals and/or animal products. The PRRS-free countries conduct risk assessments of possible scenarios for transmis- 
sion of virus through import (Neumann et al., 2005). There is a possibility of transmission through contaminated meat or animal products if the virus is present in inedible parts of meat at slaughter or after processing. If either of these is fed to swine in the country in which such products have been imported, there is likelihood of virus transmission among the resident pig population. No information is available in the literature if PRRSV is present in meat or if it can be transmitted from meat to pigs. Also, there are no data on how long the virus can survive in fresh pork. Having this information available can help in formulating import strategies. Such information would also be helpful to the exporting countries.

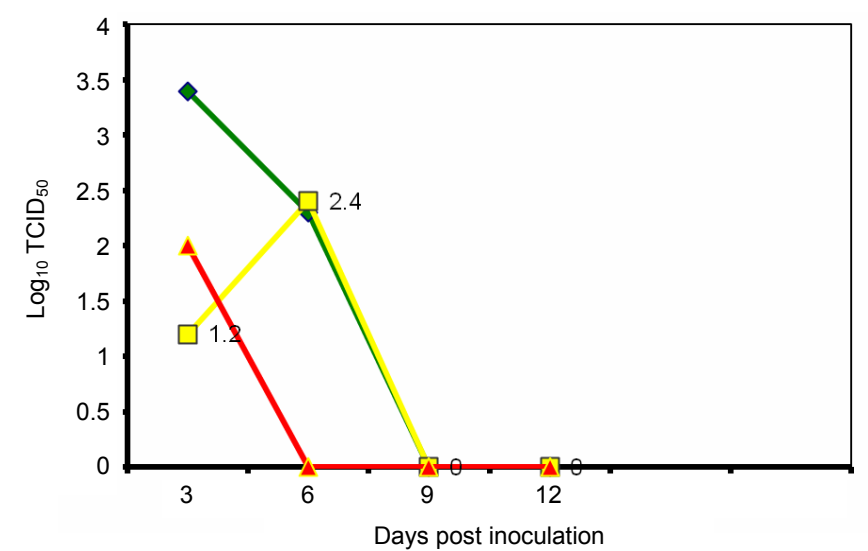

Fig. 3. Survival of PRRS virus in fresh pork at $4^{\circ} \mathrm{C}$. Lines with $\diamond, \square, \Delta$ represent virus dilution of $10^{5}, 10^{4}$ and $10^{3} \mathrm{TCID}_{50} / \mathrm{ml}$, respectively

The experimental temperatures were chosen to represent the conditions at which pork is typically handled and stored. There are only a few reports available on the survival of PRRSV or any other virus in experimentally inoculated fresh pork samples. Most of the previous studies attempted to detect the presence of virus in meat from experimentally infected animals. For PRRSV, a D-value (time taken for a $1 \log _{10}$ reduction) was estimated to be $30 \mathrm{~h}$ at $4{ }^{\circ} \mathrm{C}$ (Magar et al., 1995). Following inoculation of 6-month-old piglets, PRRSV was re-isolated within 7 days post inoculation but not at 14 days (Magar et al., 1995). In another study, the virus could be isolated from only one of 72 muscle tissues collected from 18 pigs between 3 and 70 days after exposure (Mengeling et al., 1995). PRRSV was detected after cooling pork for $24 \mathrm{~h}$ at $4{ }^{\circ} \mathrm{C}$ and for 10 days of freezing (van der Linden et al., 2003). In a study on the survival of Lelystad strain of PRRSV in muscle tissue from viraemic pigs, virus was detected in diaphragm ( 0 $\mathrm{h}$ post mortem) and in neck musculature ( $24 \mathrm{~h}$ post mortem) samples collected 5 to 10 days post inoculation (Bloemraad et al., 1994). No virus was detected in muscle tissues of pigs after $48 \mathrm{~h}$ of harvest (Bloemraad et al., 1994). In another study, samples from meat processing plants were tested by virus isolation and 
reverse transcription-polymerase chain reaction (RT-PCR). All samples were negative by virus isolation and RT-PCR (Larochelle and Magar, 1997). In another report, the presence of PRRSV in pig meat collected at slaughterhouse was studied; a total of $1.9 \%$ of meat samples were positive for PRRSV by RT-PCR. The PRRSV-positive meat samples were fed to 9-week-old pigs. It was found that these pigs were infected with PRRSV following ingestion of meat samples, indicating the potential of virus transmission following oral exposure (Magar and Larochelle, 2004). Although both of these studies are contradictory in nature, we cannot rule out the transmission of PRRSV through contaminated meat. In another study, the survival of PRRSV was evaluated in non-processed meat. Meat was collected seven days after the pigs were inoculated with a strain of PRRSV and frozen at $-20{ }^{\circ} \mathrm{C}$ for one month (Cano et al., 2007). The samples were then thawed, pieces were cut and kept at $4{ }^{\circ} \mathrm{C}$, and then tested until eight days following thawing. Viability of PRRSV was assessed by performing swine bioassay. Viable virus was detected in samples from all eight sampling days as confirmed by positive PCR and ELISA results (Cano et al., 2007).

These experimental studies demonstrate transient detection of PRRSV in muscle tissue samples, which is possibly associated with the initial amount of virus present in the meat of infected animals. The results of our study indicate that the rate of PRRSV inactivation in fresh pork is highly dependent on storage temperature and on the amount of virus initially present. The virus was able to survive for at least $48 \mathrm{~h}$ at room temperature, and for 6 and 60 days at $4{ }^{\circ} \mathrm{C}$ and $-20{ }^{\circ} \mathrm{C}$, respectively. These preliminary data on PRRSV survival in fresh pork should prove valuable in establishing guidelines and policies for import and export of fresh pork. In the present study, we used high concentrations of virus so that it was easy to monitor the presence of virus after storage of meat samples. Under actual conditions, infection with such a high dose may not occur. This indicates the need for development of methods to detect small amounts of virus in meat samples so that actual conditions can be simulated.

\section{Acknowledgement}

This study was supported in part by the National Pork Board (Des Moines, IA, USA).

\section{References}

Benfield, D. A., Nelson, E., Collins, J. E., Harris, L., Goyal, S. M., Robinson, D., Christianson, W. T., Morrison, R. B., Gorcyca, D. and Chaldek, D. (1992): Characterization of swine infertility and respiratory syndrome (SIRS) virus (isolate ATTC VR2332). J. Vet. Diagn. Invest. 4, 127-133. 
Bloemraad, M., de Kluijver, E. P., Peterson, A., Burkhardt, G. E. and Wensvoort, G. (1994): Porcine reproductive and respiratory syndrome: temperature and $\mathrm{pH}$ stability of Lelystad virus and its survival in tissue specimens from viraemic pigs. Vet. Microbiol. 42, 361-371.

Cano, J. P., Murtaugh, M. P. and Dee, S. A. (2007): Evaluation of the survival of porcine reproductive and respiratory syndrome virus in non-processed pig meat. Vet. Rec. 160, 907-908.

Dee, S. A., Deen, J., Otake, S. and Pijoan, C. (2004): An experimental model to evaluate the role of transport vehicles as a source of transmission of porcine reproductive and respiratory syndrome virus to susceptible pigs. Can. J. Vet. Res. 68, 124-133.

Farez, S. and Morley, R. S. (1997): Potential animal health hazards of pork and pork products. Rev. Sci. Tech. 16, 65-78.

Frey, M. L., Landgraf, J. G., Schmitt, B. J., Eernisse, K. A. and Pearson, J. E. (1995): Recovery of porcine reproductive and respiratory syndrome virus from tissues of slaughter weight pigs. Proc. 2nd Int. Symp. PRRSV, Copenhagen, Denmark. p. 28.

Karber, G. (1931): Beitrag zur kollektive Behandlung pharmakologischer Reiheversuche. NaunynSchmiedeberg. Arch. Exper. Pathol. Pharmakol. 162, 480-483.

Larochelle, R. and Magar, R. (1997): Evaluation of the presence of porcine reproductive and respiratory syndrome virus in packaged pig meat using virus isolation and polymerase chain reaction (PCR) method. Vet. Microbiol. 58, 1-8.

Magar, R. and Larochelle, R. (2004): Evaluation of the presence of porcine reproductive and respiratory syndrome virus in pig meat and experimental transmission following oral exposure. Can. J. Vet. Res. 68, 259-266.

Magar, R., Robinson, Y., Dubuc, C. and Larochelle, R. (1995): Evaluation of persistence of porcine reproductive and respiratory syndrome virus in pig carcasses. Vet. Rec. 137, 559-561.

Mengeling, W. L., Lager, K. M. and Vorwald, A. C. (1995): Diagnosis of porcine reproductive and respiratory syndrome. J. Vet. Diagn. Invest. 7, 3-16.

Mortensen, S., Stryhn, H., Sogaard, R., Boklund, A., Stark, K. D. C., Christensen, J. and Willeberg, P. (2002): Risk factors for infection of sow herds with porcine reproductive and respiratory syndrome (PRRS) virus. Prev. Vet. Med. 53, 83-101.

Neumann, E. J., Kliebenstein, J. B., Johnson, C. D., Mabry, J. W., Bush, E. J., Seitzinger, A. H., Green, A. L. and Zimmerman, J. J. (2005): Assessment of the economic impact of porcine reproductive syndrome on swine production in the United States. JAVMA 227, 385-392.

Otake, S., Dee, S. A., Moon, R. D., Rossow, K. D., Trincado, C. and Pijoan, C. (2003): Survival of porcine reproductive and respiratory syndrome virus in houseflies. Can. J. Vet. Res. 67, 98-103.

Otake, S., Dee, S. A., Moon, R. D., Rossow, K. D., Trincado, C. and Pijoan, C. (2004): Studies on the carriage and transmission of porcine reproductive and respiratory syndrome virus by individual houseflies (Musca domestica). Vet. Rec. 154, 80-85.

Otake, S., Dee, S. A., Rossow, K. D., Joo, H. S., Deen, J., Molitor, T. W. and Pijoan, C. (2002a): Transmission of porcine reproductive and respiratory syndrome virus by fomites (boots and overalls). J. Swine Health Prod. 10, 59-65.

Otake, S., Dee, S. A., Rossow, K. D., Moon, R. D. and Pijoan, C. (2002b): Mechanical transmission of porcine reproductive and respiratory syndrome virus by mosquitoes, Aedes vexans. Can. J. Vet. Res. 66, 191-195.

van der Linden, I. F. A., van der Linde-Bril, E. M., Voermans, J. J. M., van Rijn, P. A., Pol, J. M. A., Martin, R. and Steverink, P. J. G. M. (2003): Oral transmission of porcine reproductive and respiratory syndrome virus by muscle of experimental infected pigs. Vet. Microbiol. 97, 45-54. 